Canadian University Music Review

Revue de musique des universités canadiennes

\title{
The Music of Wagner in Toronto before 1914
}

\section{Carl Morey}

Volume 18, numéro 2, 1998

URI : https://id.erudit.org/iderudit/1014652ar

DOI : https://doi.org/10.7202/1014652ar

Aller au sommaire du numéro

\section{Éditeur(s)}

Canadian University Music Society / Société de musique des universités canadiennes

\section{ISSN}

0710-0353 (imprimé)

2291-2436 (numérique)

Découvrir la revue

\section{Citer cet article}

Morey, C. (1998). The Music of Wagner in Toronto before 1914. Canadian University Music Review / Revue de musique des universités canadiennes, 18(2), 25-37. https://doi.org/10.7202/1014652ar
Résumé de l'article

Wagner's music was first heard in Toronto in the 1860s, and in the years before 1914 it achieved extraordinary popularity. Orchestral and vocal excerpts became standard repertoire and the city enjoyed performances conducted by such notable Wagnerians as Walter Damrosch and Anton Seidl and other visitors, as well as by local musicians. There were enthusiastic local Wagnerians such as the conductors Herbert Torrington and Frank Welsman, and the pianist W. Waugh Lauder who had a personal association with Wagner through his teacher, Franz Liszt. Fully staged performances were rarer and depended entirely on touring companies, but nevertheless there were productions of Der fliegende Holländer, Tannhäuser, Lohengrin, Die Walküre, and Parsifal.
All Rights Reserved (C Canadian University Music Society / Société de musique des universités canadiennes, 1998
Ce document est protégé par la loi sur le droit d'auteur. L'utilisation des services d'Érudit (y compris la reproduction) est assujettie à sa politique d'utilisation que vous pouvez consulter en ligne.

https://apropos.erudit.org/fr/usagers/politique-dutilisation/ 


\title{
THE MUSIC OF WAGNER IN TORONTO BEFORE 1914
}

\author{
Carl Morey
}

Despite a good deal of activity in the field of Canadian musical studies, still relatively little is known about concert life in Canada-who performed and what was heard. This paper is a modest contribution to what might be called the history of repertoire in one city-Toronto-and in respect to one composer-Richard Wagner. Marie-Thérèse Lefebvre has set out a similar study in this journal in an article "La musique de Wagner au Québec au tournant du $\mathrm{XX}^{\mathrm{e}}$ siècle,"l and it is as a parallel to her investigations that the present survey is offered.

Where the works of Wagner are concerned, Canada is but a footnote to the international scene. Even today, his music dramas are seldom given in this country, and there has never been a native production of Der Ring des Nibelungen. Nevertheless, it attests to Wagner's phenomenal early success at a popular level that his music could be heard in Toronto with some frequency in the last years of his life and in the three decades following his death in 1883. Indeed, a Toronto music lover during that period had far more opportunity to hear the music of Wagner than the music of Brahms, and there were actually more opportunities to see his works on stage in Toronto in the period 18871914 than during the thirty-five years 1962-1997-fourteen productions of five works, in contrast to twelve productions of seven works. ${ }^{2}$ To be sure, the early productions were all one or two performances by touring companies whereas the productions since 1962 by the Canadian Opera Company were all locally produced in multiple performances, but it is instructive, both of the city's interests and of Wagner's early popularity, that such a comparison can even be made.

The early opportunity to hear Wagner's music in Toronto must be considered in the context of performance during his lifetime and just after his death. Although almost all his music dramas had considerable acceptance within Germany soon after their initial productions, Tannhäuser alone was widely given outside Germany in the decade following its premiere in $1845{ }^{3}$ Even Der fliegende Holländer and Lohengrin began to achieve some popularity

1 Revue de musique des universités canadiennes, no. 14 (1994): 60-76.

2 Productions of the Canadian Opera Company, the only recent producer of Wagner's works in Toronto, were determined from the program books of the Company. Earlier productions are discussed below. The COC began in 1950 and produced Die Walküre in 1962.

3 Performance information is based on Alfred Lowenberg, Annals of Opera, 1597-1940, 3rd ed., revised (London: John Calder, 1978). 
beyond Germany only in the 1860 s and 1870s. Tannhäuser was the first of Wagner's works to be seen in the United States when it was given in 1859 in New York, then again in 1864 in Philadelphia, and in 1865 in Chicago. There was nothing else until Lohengrin in 1871, and it was not until the opening of the Metropolitan Opera House in New York in 1883 that his works really began to have currency on this continent. The Metropolitan Opera was at first very much a German theatre, and during the seasons 1884-89 works were performed only in German. The United States had substantial German immigration in the nineteenth century, which Canada did not have, and Wagner himself had written an article "The Work and Mission of My Life" for the North American Review (August 1879) in which he noted "encouraging signs" from "the land beyond the ocean" for German music in the New World. At one point Wagner seems briefly to have entertained the idea of immigrating to Minnesota. ${ }^{4}$ It was during the "German" period that most of the Wagner music dramas were introduced at the Metropolitan where they made up a substantial part of the repertoire, beginning with Die Meistersinger von Nürnberg in 1885 and continuing with Tristan, Siegfried, Das Rheingold, and Der fliegende Hollander. The first Ring cycle was given in 1899.5 In North America outside New York, the most frequent experience of Wagner's music was in the concert hall, a condition that continued to be the case even after the opening of the Metropolitan Opera House.

The first record of music by Wagner heard in Toronto was a performance of the March from Tannhäuser, performed at a charity concert by four pianists at two pianos on 8 April $1862 .{ }^{6}$ The pianists were George Strathy, Carl Peiler, E. Peiler, and B. A. McDonald. Strathy, who was one of the principal local musicians, claimed to have been a student of Mendelssohn and certainly he had studied in Germany in the 1840s where he could have heard some of Wagner's early music. He frequently performed major symphonic works in Toronto in two-piano eight-hand versions. The March was performed by him again in February 1867, when Mrs. Gilbert replaced McDonald. ${ }^{7}$ It was again music from Tannhäuser that was the first work to be heard in its orchestral version when the Overture was performed by that eminent Wagnerian, Theodore Thomas and his orchestra in $1873 .^{8}$ Thomas was one of the great proselytizers on behalf of Wagner in the United States and with his orchestra he was one of the main presenters of his music before the advent of the Metropolitan Opera Company. ${ }^{9}$ No more orchestral music was heard until 1878 when Herbert

4See Burtin W. Peretti, "Democratic Leitmotivs in the American Reception of Wagner," 19thCentury Music 13, no. 1 (Summer 1989): 28-38. See also David C. Large and William Weber, eds., Wagnerism in European Culture and Politics (Ithaca, N.Y.: Cornell University Press, 1984).

5 Metropolitan Opera Annals, comp. William H. Seltsam (New York: H. H. Wilson, 1947).

6David Sale, "Toronto's Pre-Confederation Music Societies, 1845-1867" (M.A. thesis, University of Toronto, 1968), 204.

7 Ibid., 306.

8 Unless otherwise noted, all performance information is derived from notices in Toronto papers that appeared around the time of the concerts. Advertisements would normally appear several times and in various newspapers. The appearance of reviews was erratic.

9See Ezra Schabas, Theodore Thomas: America's Conductor and Builder of Orchestras, 1835 
Torrington performed the March and Chorus from the same opera in January 1878 "for the first time in Toronto," and again in June of the same year with the Toronto Philharmonic Society. If Wagner's music was not heard in those intervening five years, there was nonetheless knowledgeable interest in the composer as evidenced by the fact that during the week of 14 August 1876, the Globe published front-page bulletins about the opening of Bayreuth. Short notices on 14, 15, and 17 August noted the performances of Das Rheingold, Die Walküre, and Siegfried with brief comments on the reception of each work. On 21 August there was a long essay, apparently reprinted from an English journal, on Götterdämmerung. It was virtually without parallel that the Globe would publish reviews or similar articles on the front page, an action that attests to Wagner's power on the public imagination even in a city where his music was barely known and on a continent where there had been but a handful of performances of two of his early works.

In the last years of Wagner's life, Toronto had its own resident Wagnerian in the person of the pianist William Waugh Lauder. Lauder was born in Oshawa in 1858 and raised in Toronto where, for a time, his father was a member of the provincial legislature. ${ }^{10}$ Lauder was a brilliant pianist who studied at the Leipzig Conservatory, and during 1879-81 with Liszt at Weimar and at the Villa d'Este. Apparently he met Wagner and played for him. Even while still a very young man in Toronto he was performing the Liszt-Wagner transcriptions. At a recital in March 1877, he played Liszt's arrangement of music from Lohengrin and the March from Tannhäuser. At his farewell recital before going off to Leipzig in May 1877, he repeated the Tannhäuser March. That he was able to obtain the music for these pieces speaks well of the local music dealers as well as for the interest, if not indeed the encouragement of his teacher, Herbert Torrington. Lauder had returned to Toronto where he was teaching and frequently performing when he gave a lecture-recital on 2 February 1883 titled "Richard Wagner and the Music of the Future."11 His splendid program included Elizabeth's Prayer from Tannhäuser, Senta's Ballad from Der fliegende Holländer, and Sieglinde's "Du bist der Lenz" from act 1 of Die Walküre, all sung by Marie Blackwell. Lauder himself played transcriptions of the scene between Siegfried and the Rhine-Maidens from the beginning of act 3 of Götterdämmerung, the inevitable March from Tannhäuser, and Wotan's Farewell and the Magic Fire Music from Die Walküre, this latter selection noted as having been "Performed before Bülow in Weimar, Liszt in Rome, and Wagner in Venice." The evening concluded with Liszt's arrangement of his own Dante Symphony for four performers at two pianos. Wagner died only ten days after this concert and a month later, 10 March, Lauder gave a memorial

1905 (Urbana and Chicago: University of Illinois Press, 1989), especially 129-39.

10See Helmut Kallmann, "Lauder, W. Waugh," in Encyclopedia of Music in Canada, 2nd ed. (Toronto: University of Toronto Press, 1992). For information on Lauder and Liszt I am particularly grateful to Pauline Pocknell; see her "Liszt and His Canadian Circle," Journal of the American Liszt Society 38 (July-December 1995): 37-66.

11 The program is reprinted in Pocknell, "Liszt and His Canadian Circle," 54. A copy of the program is in the Metropolitan Toronto Reference Library (Torrington's Concert Programs). 
recital at which he played excerpts from the Ring, Tannhäuser, Lohengrin, Tristan, and Der fliegende Holländer. He was again assisted by the soprano Marie Blackwell who repeated the three excerpts that she had sung at the February recital. In an enthusiastic review of the concert the Globe writer recognized the limitations inherent in a rendering of Wagner's work on the piano; nevertheless "while the rich and sensuous colouring of his music can only be fully illustrated by a large and well-trained orchestra, it is but just to say that Mr. Lauder acquitted himself of his almost herculean task to the satisfaction of everyone present."12 In April of the same year, 1883, the Globe reported that Lauder had received a cordial letter from Liszt thanking him, in the name of Cosima Wagner, "for the energetic manner in which he has introduced such a large number of Wagner's most important and characteristic numbers from his earliest operas, as well as from his 'Nibelungen' and later compositions to the Canadian public."13 Liszt also acknowledged Lauder's performance of so many of his own original compositions as well as transcriptions and arrangements. (It might be noted in passing that Liszt was not entirely unfamiliar with Toronto. In 1881 he had sent the piano manufacturers Mason \& Risch a full-length portrait of himself as a tribute for their pianos, which Liszt knew and appreciated.) By Lauder's own reckoning, he gave about two hundred lecture-recitals in Toronto and other towns in Ontario. Pauline Pocknell has been able to trace about a quarter of these and has established that at these alone Lauder played music by Wagner at least twenty-five times. ${ }^{14}$

Lauder was not alone in offering lectures on Wagner to the public. Another local musician who had encountered Wagner's music on its home ground was Augustus Vogt, who returned to Toronto in 1888 after three years of study at the Leipzig Conservatory. In February 1889, Vogt lectured on Wagner at the Toronto College of Music (Torrington's school) with piano and vocal illustrations, but with the added attraction that he played the Prayer from Rienzi, the Pilgrim's Chorus from Tannhäuser, and the Prelude to Lohengrin on the organ. The program also included Elizabeth's Prayer and "Träume, mein Herz" from Weber's Oberon sung by Adele Strauss, Liszt's piano transcriptions of music from Der fliegende Holländer and Tannhäuser played by Harry Field, and "Thou Star Resplendent" from Tannhäuser sung by E. W. Schuch, all of them local musicians. The Women's Musical Club devoted a couple of sessions early in the century to Wagner, one of the most intriguing of which took place in February 1901. There were several songs and piano pieces as well as Siegmund's "Winterstürme" and Walter's Prize Song played on the cello, the program tied together with a lecture by Anna Farini. Madame Farini was born Anna Müller into a well-off and cultivated family in Germany and came to Canada as the wife of William Hunt from Port Hope, Ontario, an extraordinary man who gained fame and considerable fortune as a fabulous trapeze artist known as the Great Farini, as a theatrical manager and even as an explorer in

12 Globe, 12 March 1883, 5.

13 Globe, 27 April 1883, 3.

14Pocknell, "Liszt and His Canadian Circle," 55. 
Africa. ${ }^{15}$ Madame Farini had her own claim to fame as a distinguished pianist who supposedly had been a pupil of Liszt and who certainly had mementos of him, including a personal letter from him, his court jacket from Weimar, and the stub of a cigar smoked by the great pianist. If there was something of the circus about Madame Farini as well as her husband, there seems little doubt about her having been part of the Liszt-Wagner circle. On 13 February 1908, she gave another talk to introduce a concert of music by Richard Strauss and Wagner to commemorate the twenty-fifth anniversary of the latter's death. ${ }^{16}$

To return to Lauder, the mention in his 1883 program of the name of Hans von Bülow requires an aside about something that did not happen. Bülow played in nearby Hamilton in 1876, although not in Toronto at that time, but he did play in Toronto in 1890 . While it would be agreeable to report that one of the most celebrated of all Wagner's associates played something by him at these recitals, it must be recorded that he did not. Perhaps that is not so surprising when one considers that Cosima had left him for Wagner in 1869.

From the 1880s Toronto heard concert excerpts of Wagner's music with regularity. Tannhäuser was a particular favourite. The March was a popular selection and turned up in the Liszt transcription on a piano recital in November 1879, played by the organist of St. Patrick's Church, Adèle Lemaître. The Pilgrim's Chorus was heard again at a Philharmonic Concert in 1883 and again some years later, in 1890 , both times conducted by Torrington. It might be noted in passing that choral scenes were heard because Toronto always had two or three superb choirs that often, in the absence of a good local orchestra, engaged leading American orchestras, which in turn frequently included works of Wagner in their programs. Leopold Damrosch, who was responsible for installing German opera at the Metropolitan, conducted the Overture with his "Grand Orchestra" in 1882, and repeated it again the next year when he added to it a performance of Elizabeth's Prayer, sung by Sofia Scalchi (although Scalchi was a famous contralto). After that the Overture became virtually a repertoire piece and Torontonians heard it played by Torrington and his Festival Orchestra (1886), Gilmore's Band (1888-it was a popular piece with bands, and Creatore and Sousa would also play it, among many other visiting bands), an orchestra under Carl Zerrahn (1889), under Anton Seidl who added the Bacchanale (1892), Emil Paur and a New York Orchestra (1899), Hans Winderstein and the Leipzig Philharmonic (1901), Wilhelm Gericke and the Boston Symphony Orchestra (1905), Paur and the Pittsburgh Orchestra (1907, 1908), the New York Philharmonic under Stransky (1912), the London Symphony Orchestra under Arthur Nikisch (1912), the Chicago Orchestra under Frederick Stock (1912), and a number of times by the Toronto Symphony Orchestra after it was established in 1906. Not to be overlooked was an unusual

15 About Madame Farini and the Liszt connection, see Shane Peacock, The Great Farini: The High-Wire Life of William Hunt (Toronto: Viking Penguin Books, 1995), 301, 453. See also Robin Elliott, Counterpoint to a City: A History of the Women's Musical Club of Toronto (Toronto: ECW Press, 1997), 50-53.

16Elliott, Counterpoint to a City, 61 . 
performance of the Tannhäuser Overture as the opening number on a recital in 1891 by the distinguished pianist Arthur Friedheim.

It is perhaps surprising that music from Der fliegende Holländer was much slower to make its way. The pianist Rafael Joseffy played Liszt's transcription of the Spinning Song at a recital in April 1880 and repeated it the following October. Isadora Martinez sang the Legend from Der fliegende Holländer at one of Leopold Damrosch's concerts in 1883, and Carl Zerrahn conducted it in 1889 , but otherwise little was heard from the opera in the period under consideration. The same was true for Lohengrin despite the later popularity of that opera. Not even the rousing Prelude to act 3 was heard much after Leopold Damrosch introduced it in 1883, although Torrington included it on a program in 1890, and Walter Damrosch played it with the New York Symphony Orchestra in 1892.

Music from Die Meistersinger was introduced at a concert in 1890 of Torrington's Philharmonic Society when the Prize Song and finale to act 3 were performed, a concert that also included a chorus from Rienzi. The Prize Song was also heard in an improbable performance in 1891 by Richard Stoelzer, who played it on the viola d'amore, a performance so successful, apparently, that he repeated it on a return visit in 1894. Theodore Thomas played the Prelude in 1896, but it was only after 1900 that it was played frequently.

In addition to Lauder's piano transcriptions, the city first heard orchestral music from Der Ring des Nibelungen when Leopold Damrosch and the New York Symphony Orchestra played the Forest Murmurs from Siegfried in 1883, a work also given by Theodore Thomas in 1892, Walter Damrosch in 1893 and 1913, Anton Seidl in 1896, and Arthur Nikisch in 1912. The Ride of the Valkyries was introduced by Thomas in 1884, repeated by Gilmore's Band in 1888 , and by Walter Damrosch and the New York Symphony Orchestra in 1893, and with some regularity thereafter, including on a piano recital in 1908 by Fannie Bloomfield Zeisler. Thomas also gave the first local performance of Siegfried's Rhine Journey in 1896. In the same year, 1896, John Philip Sousa played what was titled "Grand Fantasia on Siegfried." The Chicago Orchestra under Frederick Stock played the Entry of the Gods into Valhalla from Das Rheingold in 1909, and the New York Philharmonic under Stransky played Siegfried's Funeral March in 1912.

After Lauder, the city's further acquaintance with the music of Tristan und Isolde was made when Seidl conducted the "Liebestod" in 1893, but it was in 1902 that the work was more extensively presented in an unusual manner. Lilli Lehmann had sung the first American Isolde in 1886, and at her recital in Toronto in 1902 she sang excerpts from the work for which she was famous. The reviewer for the Globe found "this part of the programme was the most interesting, as it was associated with an instructive explanation of the design and scope of the opera by Mr. Reinhold Hermann, who illustrated his remarks on the pianoforte with a number of selections from the work." ${ }^{17}$ In 1905 Paur

17 Globe, 7 January 1902, 9. 
and the Pittsburgh Orchestra finally added the Prelude to the "Liebestod," music that was subsequently conducted by Walter Damrosch, Frederick Stock, Frank Welsman with the Toronto Symphony Orchestra, and, almost inevitably, Sousa (and Toscanini with the La Scala Orchestra in 1921). Stock conducted the Love Scene and Brangäne's Warning from act 2 in January 1910 as an orchestral excerpt.

At least one work by Wagner was so common an item on orchestra programs after the mid-1880s that the more noteworthy concert was one given over in large part or entirely to Wagner. As early as 1883 at one of his concerts in May, Leopold Damrosch devoted half the program to Wagner with the Overture and Elizabeth's prayer from Tannhäuser, the Prelude to act 3 of Lohengrin, Senta's ballad from Der fliegende Holländer, the Forest Murmurs from Siegfried and the Kaiser Marsch. In May 1890 the ambitious spring concert of the Toronto Philharmonic Society under Herbert Torrington was devoted completely to Wagner with a program that included the Overture and Chorus of the Messengers of Peace from Rienzi, the March and Pilgrim's Chorus from Tannhäuser, extensive excerpts from Lohengrin that included Elsa's Prayer and the finale to act 1, the Bridal Chorus and the Prelude to act 3, the duet for Senta and the Dutchman from act 2 of Der fliegende Holländer, the Prize Song, the Chorale "Wach'auf" and the finale to Die Meistersinger. In November of the same year, 1890 , the Philharmonic Society assisted at three concerts given by the Boston Festival Orchestra under Carl Zerrahn, who had been one of the pioneering Wagnerites in the United States and in whose orchestra Torrington had played violin in 1870 during his Boston years. ${ }^{18}$ The opening concert on 24 November included the Ride of the Valkyries, the scene of the Chief Messenger from Rienzi, and the March from Tannhäuser. At the afternoon performance the next day the orchestra performed the overtures to Der fliegende Holländer and Rienzi, while in the evening the program included the Overture and Pilgrim's Chorus from Tannhäuser and the finale to Die Meistersinger. It was probably around this time that Torrington was able to consolidate his interest in Wagner with a visit to Bayreuth where he attended performances of Tannhäuser and Parsifal. ${ }^{19}$

Torrington was not the only musician with Toronto associations to hear Wagner in Germany. W. Waugh Lauder, Augustus Vogt, Frank Welsman, W. O. Forsyth, Evelyn Street, Nora Clench, Harry Field, Frank Blachford, Lina Adamson, to name a few, all studied in Leipzig and brought home first-hand experience of German music, including Wagner. The noted pianist and composer, W. O. Forsyth, did not at first care for the "continual roaming around without rhythm or form" or the "shrieking discords" of Wagner's music, but he soon became an enthusiast. ${ }^{20}$

18Zerrahn had appeared in Toronto with the celebrated Germania Musical Society in 1850 and 1852 (a reduced group also visited in 1856), but nothing by Wagner was included in their local programs.

19From an undated biographical manuscript note in the Torrington Papers, Baldwin Room, Metropolitan Toronto Reference Library. The visit was likely in the 1890 s.

20Elaine Keillor, "Auf kanadischer Welle: The Establishment of the Germanic Musical Canon in Canada," in Music in Canada/La musique au Canada, ed. Guido Bimberg (Bochum: Universitätsverlag 
Among the most "authentic" Wagner performances that Toronto heard were the concerts lead by Anton Seidl in the 1890s. Seidl had been Wagner's assistant for five years and helped prepare the first performance of the Ring at Bayreuth. He subsequently became one of the most admired conductors of Wagner's works and went to the Metropolitan Opera in 1885 where he succeeded Leopold Damrosch and shared conducting duties with Walter Damrosch. A fire in the Metropolitan Opera House in 1892 caused the cancellation of the 1892-93 season, and Seidl took members of his company on tour. At his first concert in Toronto in November 1892, Seidl conducted a miscellaneous concert that included Elsa's Dream, sung by Amanda Fabris, and the Overture and Bacchanale from Tannhäuser. When he returned next 4 April 1893, he presented an all-Wagner concert that introduced some new music to the city. There were once again the Tannhäuser and Lohengrin excerpts but also the Prelude to act 1 and the duet for Elsa and Ortrud (sung by Emma Juch and Fabris) from act 2 of Lohengrin, the "Liebestod" (orchestra only) from Tristan und Isolde, the quintet from Die Meistersinger, the scene for Brünnhilde (Carola Riegg), Sieglinde (Emma Juch) and the Valkyries from act 3 of Die Walküre, the Forest Murmurs from Siegfried, and the Prelude and Glorification from Parsifal. At another concert on 22 April, Seidl included the Spinning Song and the Legend from Der fliegende Holländer, and the scene from Parsifal of the Flower Maidens and Parsifal (William Stephens). Unusual at this concert was the opportunity to hear Seidl accompany Juch at the piano in the performance of two of the Wesendonk songs, Schmerzen and Träume, and the Wiegenlied. (Träume had been heard at least once before when Lilli Lehmann sang it at a concert in May 1886.) Seidl returned to Toronto only once more, in October 1896, and gave two concerts in which the only Wagnerian repertoire was the Forest Murmurs and an unidentified excerpt from Die Meistersinger.

In the fall of 1912 there was a week-long grand festival to open the new Mutual Street Arena. The resident orchestra for the event, even though the Toronto Symphony Orchestra was flourishing by then, was a New York ensemble conducted by Nahan Franko. Franko was concert-master of the Metropolitan Opera orchestra from the opening of the company for twenty-five years and had played under the great Wagnerian conductors who had worked in that house. His daily concerts during the festival included two excerpts from Die Meistersinger, the Entry of the Gods into Valhalla, the overture to Rienzi, Elsa's Dream, sung by Johanna Gadski, and Adriano's aria from Rienzi sung by Rosa Olitzka. The Wagnerian climax came at the penultimate concert of the week, which included the overtures to Tannhäuser and Parsifal, Wotan's Farewell and the Magic Fire Music, the "Liebestod" sung by Olive Fremsted, and the duet for Ortrud and Elsa from Lohengrin sung by Fremsted and Olitzka.

When the New York Symphony Orchestra under Josef Stransky appeared as guests with the National Chorus in January 1913, the Chorus sang a few miscellaneous part-songs, but the orchestra played the overtures to Die

Dr. N. Brockmeyer, 1997), 59. 
Meistersinger, Rienzi, and Lohengrin, the Forest Murmurs from Siegfried, the Good Friday Spell from Parsifal, and the Prelude and "Liebestod" from Tristan.

Concerts, then, were the vehicle for the introduction of Wagner's music, chiefly by visiting orchestras and conductors. The pattern continued through to 1914 , but with many more locally produced performances after the establishment in 1906 of an orchestra under the auspices of the Toronto Conservatory that almost immediately became officially the Toronto Symphony Orchestra. The conductor was the Toronto musician Frank Welsman, who had been a student at the Leipzig Conservatory where he seems to have developed an enthusiasm for Wagner. In each of the seasons from 1908 to 1911 the Orchestra had among its soloists the soprano Johanna Gadski, who had sung at Bayreuth and who, after her debut at the Metropolitan in 1900 became that company's leading Brünnhilde and Isolde. Gadski sang the great soprano scenes from Tannhäuser, Die Walküre, Tristan und Isolde, and Lohengrin. Among other vocalists who performed Wagner with the Orchestra were David Bispham, who sang Wotan's Farewell in December 1909, and Leo Slezak who sang the Prize Song in January 1912. Welsman conducted an all-Wagner concert in November 1911 at which the Orchestra played the overtures to Der fliegende Holländer, Lohengrin, and Tannhäuser as well as Siegfried's Funeral March, and Gadski sang Elsa's dream, "Dich, teure Halle" from Tannhäuser, and the Immolation scene from Götterdämmerung. In the course of its other seasons, the Toronto Symphony Orchestra played on numerous occasions music from Die Meistersinger, Rienzi, Tannhäuser, Tristan, the Siegfried Idyll, and the finale to act 1 of Parsifal with the National Chorus (1910).

From this exposition of events, it should be evident that Torontonians were well served in the concert hall. They not only heard regularly a good deal of Wagner's music, they frequently heard it performed by some of the greatest interpreters of the day. If they had less opportunity to hear Wagner in the theatre, they were not entirely without the experience. The first full production of a Wagner opera heard in the city was given by the National Opera Company when that Company included Der fliegende Holländer in its season in the city in June 1887. In the verbose but understated style of the time, the Globe reported that "to say that the first performance of Wagnerian opera in Toronto was a success is to give but small expression to the popular verdict rendered last night at the Toronto Opera House, when the Flying Dutchman was performed."21 Emma Juch was Senta, William Ludwig was the Dutchman, Myron W. Whitney was Daland, and the conductor was Gustav Hinrichs. This was the troupe organized by Theodore Thomas, the accommodation of whose orchestra of sixty players required the removal of the first four rows of seats in the theatre. When the Company returned the following January 1888, it gave Lohengrin, which was to become the most frequently heard Wagner work in the city. It was heard again in October 1890 with Juch as Elsa and Charles Hedmont as Lohengrin, in 1893 with Marie Tavary, in October 1901 in a brilliant perfor-

21 Globe, 17 June 1887, 8. 
mance conducted by Walter Damrosch with Marcella Sembrich, Louise Homer, and Jacques Bar, in 1904 and 1905 by the Henry W. Savage Company, in 1912 by the Aborn English Grand Opera Company, and in 1914 by the National Grand Opera Company of Canada from Montréal. Juch also added Tannhäuser to the local repertoire in October 1891 and it was given again by Savage in 1904 and in 1905. The Savage Company also gave two performances of Die Walküre in November 1905 to overflow audiences with the Canadian tenor Francis Maclennan as Siegmund. Even the immorality of the story was put aside by puritan Toronto for this, "the culminating event of the week": "The repellent nature of the symbolic story that Wagner selected as enforcement of his idea counted for naught against the potent attraction of the music."22 In a long article about the work, the critic E. R. Parkhurst recognized the vocal shortcomings of the Savage Company in the face of such extraordinary demands,

And yet one is deeply indebted to the Savage company for their daring enterprise in producing the Valkyrie. Those of our local audience who cannot find opportunity to go to Europe or New York during the opera season derived an intellectual pleasure in hearing Wagner's great work presented in a manner that at least gave a clear idea of the design of the score, of the import and intensity of the drama .... ${ }^{23}$

Toronto had, in fact, been prepared for Die Walküre when the Women's Musical Club presented a special lecture on the piece the previous April by Evelyn Choate of Buffalo. ${ }^{24}$ As was the custom at the time, almost all of the productions were sung in English.

Of all the Wagner music dramas introduced to the city in the early years of the century, none produced a greater furor than Parsifal. Toronto had heard the Prelude less than four months after the Bayreuth premiere when Leopold Damrosch conducted it in November 1882. Already mentioned above was Seidl's performance of the Flower-Maiden scene in 1893. Theodore Thomas presented the Prelude in 1895 to which he added the final "Glorification" scene, as did Paur in 1906. But as for the music drama itself, it is well known that Wagner intended to confine its performance exclusively to Bayreuth, and the work was legally protected for a period of thirty years after his death, that is to say, until 1913. Nevertheless, there were concert performances in London in 1884 and New York in 1886, and Seidl gave an evening of excerpts at the Metropolitan in $1891 .{ }^{25}$ Finally it was staged in New York in 1903 despite Cosima Wagner's attempts to halt the production with legal action, although she did maintain the ban in Europe. The legal situation hinged on the fact that the United States did not join the Berne Copyright Union of 1886 under which Cosima could claim protection in most European countries. Technically, it 
appears that Parsifal was protected in Canada through the Berne convention, but presumably Cosima never gave a thought to a performance in Canada, and probably it did not occur to the American producers to differentiate between Canada and the United States.

In April 1904, advertisements appeared in the Toronto papers for "The Greatest Musical Event of the Season, Parsifal," the implication clearly being that the entire work would be given. In fact it was a program of substantial excerpts performed on 5 April 1904, the day after Easter Monday, with soloists and the New York Symphony Orchestra conducted by Walter Damrosch. The program began with the Prelude to Die Meistersinger and continued with music from Parsifal - from act 1: Prelude, March of the Knights of the Holy Grail, and the invisible chorus; Amfortas's lament and prophecy; from act 2: Parsifal and the Flower Maidens, Kundry's Song; from act 3: Good Friday Spell, Parsifal becomes King of the Grail and heals the wound of Amfortas. The soloists were the Canadian baritone Francis Archambault, tenor Dan F. Beddoe, and soprano Mihr-Hardy. As seems to have been not uncommonly the case with Wagner concerts, there was a lecture feature to it. There were "explanatory comments with which Mr. Damrosch prefaced each division of the recital" and "he quoted by reference to the piano the principal symbolic motives employed by Wagner." 26

Finally in 1905 Henry Savage's company gave four performances of Parsifal at the Princess Theatre, 24-26 April. ${ }^{27}$ Evening performances were at 5:30 with an intermission after the first act from 7:15 to 8:30 for dinner, with a Saturday matinee that began at 11:00 with an hour intermission for lunch. The roles of Parsifal and Kundry were triple cast, the rest of the roles double cast. ${ }^{28}$ The event generated unprecedented interest in the press and among the public and the Globe published lengthy articles about the Savage Company, the Grail legends and the work itself on 8 April, 15 April, and in the magazine section on 22 April. Albert Ham, a distinguished teacher at the Conservatory and conductor of the National Chorus, gave an illustrated lecture on Parsifal on 10 April, with musical examples performed by an orchestra. ${ }^{29}$ Another lecture was given at the theatre on 18 April by Rubin Goldmark, "the foremost Wagnerian lecturer in the country" who demonstrated his lecture at the piano. ${ }^{30}$ When tickets went on sale the advance mail orders exceeded all records for the Princess Theatre ${ }^{31}$ and early lines formed when the box-office opened:

26 Globe, 6 April 1904, 14.

27Four performances followed in Montréal, 27-29 April; see Lefebvre, "La musique de Wagner au Québec au tournant du XX $\mathrm{XX}^{\mathrm{e}}$ siècle," 72. Savage had assembled this company specifically to produce Parsifal and had already taken it to Chicago, Boston, Cincinnati, and St. Louis. He did not produce only grand opera. Two weeks before Parsifal, Savage had brought to Toronto "the Korean comic opera The Sho-Gun," also at the Princess Theatre (Globe, 13 April 1905, 2), and in 1907 he would introduce The Merry Widow to America. See John Dizikes, Opera in America (New Haven, Conn., and London: Yale University Press, 1993), 312, 370.

28The singers are listed in a long article on the forthcoming production in the Globe, 22 April 1905, 11.

29 Article in the Globe, 8 April 1905, 13.

30 Globe, 17 April 1905, 12. Goldmark lectured throughout the United States and Canada, and from 1924 was head of composition at the Juilliard School, New York. 
The Parsifal advance sale of seats which opened yesterday morning at 9 o'clock at the Princess Theatre, will take the record in receipts for any opera performances given in this city. Before midnight on Wednesday there was a long line of people extending from the doors of the theatre along King street west, who by 7 o'clock yesterday morning were reinforced by new arrivals, until the crowd passed Simcoe street and turned south. ${ }^{32}$

There were even ticket speculators. The first performance was given a long glowing review headlined "Parsifal An Impressive Work. Successful First Production In Toronto. Audience Spellbound," and was printed on the front page of the Globe, ${ }^{33}$ a distinction that had a parallel only in the front-page bulletins from Bayreuth in 1876.

Parsifal has not been given in Toronto again.

An event that did not happen was an announced two-week visit in the spring of 1914 by the Quinlan Opera Company, which had made a specialty of Wagner and had introduced the Ring to Montréal. ${ }^{34}$ Audiences had been poor in Montréal and this decided the Quinlan Company to cut its losses and terminate its tour there. ${ }^{35}$ A proposal for a return in the fall was not realized after the declaration of war in the summer of 1914.

The outbreak of war in 1914 and the unsettled economic state of the years from 1918 to 1939 brought about the end of the big touring opera companies. ${ }^{36}$ The only Wagner operas given in the 1930s were local productions of Tannhäuser in 1937 and Lohengrin in 1939, the latter conducted by Sir Ernest MacMillan. MacMillan was always an enthusiastic Wagnerian-indeed, it had been a visit to Bayreuth in 1914 that led to his internment as an enemy alien in Germany for the duration of the war-and he presented all-Wagner concerts in his first two seasons, 1931 and 1932, as conductor of the Toronto Symphony Orchestra as well as in several seasons thereafter. But the city did not have the resources to mount its own full productions. On its spring tours, the Metropolitan Opera performed Lohengrin in 1953 and Die Walküre in 1984. Toronto did not have a permanent opera company of its own until 1950 and that organization, the Canadian Opera Company, did not give its first Wagner opera until 1962 when it presented Die Walküre. An attempt to produce a Ring cycle in the early 1970s did go as far as the last three works, but before Das Rheingold could be added the project was abandoned by a nervous Board of Directors who feared the financial obligations of the complete venture. To some extent modern audiences are probably victims of raised expectations in the electronic age when recordings make available famous artists in sonically impressive performances and commentaries to live radio broadcasts convey an impression

31 Globe, 19 April 1905, 14.

32Globe, 21 April 1905, 12.

33 Globe, 25 April 1905, 1.

34Lefebvre, "La musique de Wagner au Québec au tournant du $\mathrm{XX}^{\mathrm{e}}$ siècle," 73.

35 Globe, 13 April 1905.

36The importance of touring companies and their decline is treated by Dorith Cooper in "Opera in Montréal and Toronto: A Study of Performance Traditions and Repertoire, 1783-1980" (Ph.D. diss., University of Toronto, 1983). 
of scenic grandeur on the unseen stage. Despite the distinguished singers and conductors who brought Wagner to Toronto and to many other cities on this continent, we know that their forces were often smaller than what we now consider to be indispensable for Wagner, and we have undoubtedly lost some of the ability to find enjoyment in the works for themselves rather than for how they are performed. Damrosch's orchestra in 1882, when he performed the Prelude to Parsifal consisted of fifty-five players. The orchestra for Juch's Lohengrin in 1888 numbered fifty players. Most of the theatres in which these performances were given have now vanished, but one, the Royal Alexandra is still in use as a distinguished playhouse after ninety years. The National Grand Opera of Canada presented Lohengrin there in 1914 and the Quinlan Opera Company proposed to give Tristan und Isolde and Die Meistersinger there before its tour was abruptly ended in 1914. Wonderful as the Royal Alexandra is, and serviceable as it was for the early years of the Canadian Opera Company, the orchestra pit, even enlarged, seats fifty players with difficulty, and it is unimaginable now that any of Wagner's dramas be performed in that theatre. Be that as it may, even in Toronto in the three decades between Wagner's death and the outbreak of war, the Music of the Future was very much Music of the Present.

\footnotetext{
Abstract

Wagner's music was first heard in Toronto in the 1860s, and in the years before 1914 it achieved extraordinary popularity. Orchestral and vocal excerpts became standard repertoire and the city enjoyed performances conducted by such notable Wagnerians as Walter Damrosch and Anton Seidl and other visitors, as well as by local musicians. There were enthusiastic local Wagnerians such as the conductors Herbert Torrington and Frank Welsman, and the pianist W. Waugh Lauder who had a personal association with Wagner through his teacher, Franz Liszt. Fully staged performances were rarer and depended entirely on touring companies, but nevertheless there were productions of Der fliegende Holländer, Tannhäuser, Lohengrin, Die Walküre, and Parsifal.
} 